\title{
Kształtowanie się współczesnego paradygmatu niepełnosprawności
}

\section{Development of a modern paradigm of disability}

\author{
Marcin Kolwitz, Iwona Radlińska \\ Katedra i Zakład Zdrowia Publicznego Pomorskiego Uniwersytetu Medycznego w Szczecinie \\ ul. Żołnierska 48, 71-210 Szczecin \\ Kierownik: prof. dr hab. n. zdr. Beata Karakiewicz
}

\section{SUMMARY}

The aim of this study was to show the evolution of the paradigm of disability associated with the scientific discourse, but also social and cultural changes. The problem of people with disabilities has existed since the beginnings of civilization, and with its development the concept of disability has also evolved. The individual problems of a patient have, over time, been treated as a medical problem associated with the disease, including its effects on physical and mental health. After World War II there were significant changes in the perception of disability and disabled people, which was associated with the rise of medical sociology and the emergence of new descriptions of diseases. New discourse on people with disabilities meant that they began to participate more frequently in public debate. This, in turn, had an impact on the attitudes of society and social policy towards people with disabilities. The model of disability evolved, and disability was finally treated as a social problem with an impact on the functioning of the whole society.

Key words: disability, disabled person, social policy, social problem, sociology of medicine.

\section{STRESZCZENIE}

Celem pracy było ukazanie ewolucji paradygmatu niepełnosprawności związanego zarówno z dyskursem naukowym, jak i zmianami społeczno-obyczajowymi. Problem ludzi niepełnosprawnych istnieje od początków cywilizacji, a wraz z jej rozwojem ewoluowało samo pojęcie niepełnosprawności. Indywidualny problem chorego z czasem zaczął być traktowany jako problem medyczny związany z chorobą i jej skutkami fizycznymi oraz psychicznymi. Po II wojnie światowej nastąpiły znaczące zmiany w postrzeganiu problemu niepełnosprawności i osób niepełnosprawnych, co było związane z powstaniem socjologii medycyny i pojawieniem się nowego opisu zjawiska choroby. Nowy dyskurs dotyczący niepełnosprawnych spowodował, że osoby te zaczęły coraz częściej zabierać głos w debacie publicznej. Miało to z kolei wpływ na postawy społeczeństwa i politykę społeczną wobec osób niepełnosprawnych. Ewolucja modelu niepełnosprawności spowodowała więc, że zaczęto traktować to zjawisko jako problem społeczny rzutujący na funkcjonowanie całego społeczeństwa.

Słowa kluczowe: niepełnosprawność, osoba niepełnosprawna, polityka społeczna, problem społeczny, socjologia medycyny.
Słowo „niepełnosprawność” wiąże się brakiem, ograniczeniem i dysfunkcją, które wpływają na przebieg życia osoby nimi dotkniętej. Jako niepełnosprawne można więc zdefiniować osoby, które mają długotrwale naruszoną sprawność fizyczną, umysłową lub intelektualną, co może w oddziaływaniu z różnymi barierami utrudniać im pełny i skuteczny udział w życiu społecznym, na zasadzie równości z innymi osobami [1].

Problem niepełnosprawnych w społeczeństwie jest wielowymiarowy. Wielowymiarowość ta wynika z tego, że niepełnosprawność dotyczy wielu dziedzin życia i jest z nią związanych wiele jednostek chorobowych. Pojęcie choroby jest ściśle związane z niepełnosprawnością. Każda choroba stanowi ograniczenie bądź obniżenie pełnej efektywności i sprawności działania zarówno ludzkiego organizmu, jak i człowieka pojmowanego w całości jako istota ludzka.

Charakterystyczne dla niepełnosprawności (tak jak innych chorób) jest to, że dotyczy zarówno osoby nią dotkniętej, jak i jej najbliższych oraz innych osób mających kontakt z niepełnosprawnymi. Ich opieka może być niepełnosprawnemu niezbędna.

Druga immanentna cecha niepełnosprawności to jej nieokreślony status. Trudno jest jednoznacznie stwierdzić czy osoba niepełnosprawna jest zdrowa, czy chora [2]. Określenie statusu niepełnosprawności zależy więc od sposobu definiowania choroby.

Jeśli więc uznamy chorobę za stan patologiczny, objawiający się dysfunkcjonalnością bądź niewydolnością narządu lub organu oraz ograniczający i uniemożliwiający pełnienie przez jednostkę ról społecznych, to niepełnosprawność możemy uznać za chorobę. Z drugiej jednak strony ta sama definicja określa chorobę jako wyraz patologii postrzeganej przez samego chorego jako stan upośledzenia i dyskomfortu o zróżnicowanym nasileniu [3].

Element samookreślenia powoduje, że niepełnosprawność nie musi spełniać przesłanek choroby, gdyż bycie osobą niepełnosprawną nie zawsze determinuje postrzeganie swojego 
życia przez pryzmat ograniczeń. Niepełnosprawność jako stan wrodzony, a także przystosowanie się do tego stanu mogą spowodować, że niepełnosprawny nie tylko potrafi sprawnie funkcjonować, ale to funkcjonowanie będzie się wiązać z tzw. dobrym samopoczuciem społecznym [4]. Oznacza to z kolei, że osoba niepełnosprawna nie musi wyrażać potrzeb zdrowotnych związanych ze swoim stanem. Spojrzenie subiektywne samej osoby niepełnosprawnej może być więc niezgodne z obiektywnym opisem choroby.

Spojrzenie obiektywne dotyczy aspektu medycznego i określa niepełnosprawność jako odstępstwo od istniejącej normy biologicznej zarówno w wymiarze fizycznym, jak i psychicznym. Jest to tzw. pierwotne ograniczenie sprawności, czyli fizjologiczna lub anatomiczna wada organizmu, które redukując lub uniemożliwiając uczestniczenie niepełnosprawnemu w życiu codziennym (np. samodzielność) i społecznym (np. praca zawodowa), powoduje upośledzenie, czyli wtórne ograniczenie sprawności [5].

Upośledzenie w wymiarze socjologicznym oznacza z kolei ograniczenie lub uniemożliwienie wypełniania ról przynależnych danej osobie.

Funkcjonowanie osób niepełnosprawnych w życiu społecznym zależy w znacznej mierze od charakteru ich relacji z osobami zdrowymi. Relacje te charakteryzują się dysonansem poznawczym, co dotyczy szczególnie osób zdrowych. Charakterystyczną cechą we wzajemnej komunikacji jest poczucie wstydliwej odmienności objawiającej się przykrymi doznaniami podczas wzajemnego kontaktu. Pojawiają się wtedy takie bariery komunikacyjne, jak: ostrożne dobieranie słów, nie patrzenie rozmówcy w oczy, sztuczne zachowywanie powagi bądź stwarzanie swobodnej atmosfery podczas rozmowy. Na pojawienie się dysonansu poznawczego wpływa brak doświadczenia we wzajemnych interakcjach. Dysonans ten może zostać przezwyciężony poprzez poprawę i normalizację wspólnych relacji (tzw. wyparcie dewiacji). Normalizacja powinna być najpierw poprzedzona ograniczaniem i przełamywaniem wzajemnej niechęci. Dzięki normalizacji osoba niepełnosprawna zaczyna być traktowana tak samo jak pełnosprawna. Wadą normalizacji jest oczekiwanie od niepełnosprawnego, że będzie się zachowywał zgodnie z naszymi oczekiwaniami i wyrażał postawę wdzięczności za okazaną pomoc, nie wysuwając roszczeń [6].

Brak relacji z osobami niepełnosprawnymi nierzadko wpływa też na postawy negatywne wynikające z rozpowszechnionych stereotypów (np. „osoba niepełnosprawna nie nadaje się do pracy") bądź z niewiedzy. Postawy negatywne mogą się objawiać w piętnowaniu, odrzucaniu i izolowaniu niepełnosprawnych. Inne typy postaw negatywnych to okazywanie litości i nadmiernego współczucia oraz nadopiekuńczość. Można je określić jako negatywne, tym bardziej, jeśli wypływają z fałszywych pobudek (poprawność polityczna i obawa, aby nie zostać uznanym za dyskryminującego niepełnosprawnych oraz nieczułego na ich sytuację), a nie z rzeczywistej potrzeby udzielenia wsparcia osobie niepełnosprawnej.

Postawy negatywne wobec niepełnosprawnych są obserwowane także u pracowników socjalnych (zbiurokratyzowanie, brak empatii) oraz pracowników ochrony zdrowia (brak wiary w poprawę stanu zdrowia i funkcjonowania niepełnosprawnego pacjenta, paternalizm, obojętność, lekceważenie, bagatelizowanie skarg, niekulturalne traktowanie) [7].

We wzajemnych relacjach sprawnych i niepełnosprawnych spotykane są też postawy obojętności będące nierzadko pochodną zmian kulturowych w społeczeństwie. Dopiero po nawiązaniu bliższych relacji między osobami sprawnymi i niepełnosprawnymi pojawiają się postawy wzajemnej akceptacji.

Pozytywną reakcją w stosunku do osób niepełnosprawnych jest wsparcie materialne, fizyczne, emocjonalne udzielane zarówno przez rodzinę, znajomych, wolontariuszy oraz organizacje pozarządowe, jak i przez instytucje publiczne.

Postęp naukowo-techniczny spowodował większe możliwości pomocy niepełnosprawnym, ale jednocześnie rośnie też liczba potrzebujących. Wpływ na to ma rozwój medycyny zmniejszający zachorowalność i śmiertelność w niektórych chorobach oraz duża liczba konfliktów zbrojnych i rozwój techniki powodujące liczne urazy.

Natura warunkuje to, że człowiek w odróżnieniu od zwierząt posiada pewien poziom empatii pozwalający nie pozostawać obojętnym na los bezradnych przedstawicieli tego samego gatunku, co wpływa na stosunek do niepełnosprawnych. Znaczenie mają również i inne czynniki. Można do nich zaliczyć religię, wychowanie czy wzorce kulturowe obowiązujące w społeczeństwie.

W tradycyjnym paradygmacie niepełnoprawności zjawisko to traktowano w kategoriach moralnych, osoby niepełnosprawne uważając za naznaczone przez Boga (przy czym nie zawsze to naznaczenie było rozumiane negatywnie). Co prawda wyjaśniano istnienie zjawiska niepełnosprawności jako dopustu bożego czy nawet kary za grzechy własne lub przodków, ale zdarzało się też, że osoby niepełnosprawne były uważane za wybrane i otaczane szczególną czcią, a nawet kultem. Różny (w zależności od obowiązującej kultury i rodzaju niepełnosprawności) był też udział osób niepełnosprawnych w życiu społecznym. Czasem izolowano je (np. w przypadku trądu), ale nierzadko włączano do społeczeństwa (jeśli uważano za niegroźne dla otoczenia), angażując w miarę możliwości do codziennych prac. Rozwijała się też opieka nad osobami niepełnosprawnymi, szczególnie w okresie średniowiecza, na co wpływały nakazy miłosierdzia i jałmużny. Opieka ta w niewielkim stopniu miała charakter medyczny, gdyż ówczesna medycyna często nie potrafiła zarówno wskazać przyczyn niepełnosprawności, jak i leczyć jej skutków.

Okres nowożytny w historii ludzkości wiązał się ze wzrostem liczby osób niepełnosprawnych. Wpływ na to zjawisko miały liczne wojny i związane z nimi powszechny pobór do wojska oraz rozwój artylerii. Rozwój cywilizacyjny zmienił sytuację niepełnosprawnych, ale okazała się ona niekorzystna. Nowocześniejszy przemysł wpłynął na zapotrzebowanie na pracę bardziej wydajną i efektywną. Niepełnosprawni, którzy mogli się sprawdzić w prostych pracach rolniczych, w fabrykach okazywali się nieprzydatni, stając się dodatkowym ciężarem dla bliskich. Zaczęło to wpływać negatywnie na sposób ich postrzegania. Wszystkie te czynniki spowodowały, 
że powiększająca się grupa osób niepełnosprawnych zaczęła być poważnym problemem dla ówczesnych państw.

W XIX w. nastąpił rozwój państwowej opieki nad niepełnosprawnymi. Dotychczasowe czynniki kreujące tę opiekę, miłosierdzie i indywidualna, niczym nieprzymuszona pomoc, zostały zastąpione przez powinności urzędników. Przejmowanie odpowiedzialności przez instytucje publiczne oraz koncentracja wyłącznie na zysku jako najważniejszym czynniku w życiu społecznym i gospodarczym (wpływ rewolucji przemysłowej) wraz z pojawieniem się poglądów filozoficznych zrywających z chrześcijańską wizją miłosierdzia oraz miłości bliźniego (Nietzsche) miały się wkrótce okazać brzemienne w skutkach. Odzwierciedleniem tych idei było pojawienie się w XX w. eugeniki, która za cel swoich działań przyjęła stopniową eliminację „niepełnowartościowych” osób (głównie upośledzonych umysłowo).

W wyniku poglądów eugenicznych w niektórych państwach (Szwecja, Finlandia, Dania, Szwajcaria, Japonia), a także w 30 stanach USA wprowadzono selekcję urodzeń poprzez przymusową sterylizację upośledzonych umysłowo kobiet. Wywierano też naciski na kobiety, aby dokonywały aborcji, gdy istniało prawdopodobieństwo urodzenia dziecka niepełnosprawnego [8].

Na najszerszą skalę eugenika znalazła zastosowanie w hitlerowskich Niemczech. Wkrótce po przejęciu władzy przez Adolfa Hitlera została uchwalona ustawa o zapobieganiu narodzinom potomków osób obciążonych dziedzicznie. Weszła ona w życie w 1934 r., sankcjonując przymusową sterylizację osób z szeroko rozumianym upośledzeniem umysłowym [9].

Dalszą konsekwencją poglądów eugenicznych była w Niemczech eutanazja. Według doktryny narodowo-socjalistycznej niepełnosprawni umysłowo, ludzie trwale niezdolni do pracy i wymagający stałej opieki (w tym dzieci z wadami umysłowymi i fizycznymi) byli uważani za pozbawionych prawa do życia. Uważano, że państwo musi wydawać na opiekę nad nimi niepotrzebnie środki i zatrudniać fachowy personel zamiast wykorzystać zasoby ludzkie oraz materialne do innych celów. Eutanazja miała więc oprócz względów ideologicznych także podłoże ekonomiczne. Już po wybuchu wojny, w październiku 1939 r. Hitler wydał naczelnemu lekarzowi III Rzeszy prof. Karlowi Brandtowi tajny rozkaz przeprowadzenia akcji uśmiercenia osób niepełnosprawnych. Akcja została nazwana Euthanasieprogramm. Szacuje się, że w latach 1939-1940 zamordowano w Niemczech 140 tys. niepełnosprawnych dorosłych, a w latach 1940-1945 - 100 tys. niepełnosprawnych dzieci [10]. Eutanazji na skalę masową dokonywano też w szpitalach psychiatrycznych okupowanej Polski.

Kataklizm, jakim była II wojna światowa, spowodował nie tylko przewartościowanie dotychczasowej polityki międzynarodowej, ale wpłynął też na konieczność rozwiązania wielu problemów politycznych, społecznych czy ekonomicznych. Powstanie Organizacji Narodów Zjednoczonych (ONZ) spowodowało ukształtowanie się nowego porządku w świecie i umiędzynarodowienie tych problemów.

Uchwalenie w 1948 r. Powszechnej deklaracji praw człowieka wpłynęło na podniesienie kwestii dotyczących różnych grup społecznych i kulturowych; wiele środowisk zaczęło się domagać swoich praw. Spowodowało to również zmiany w postrzeganiu zjawiska niepełnosprawności.

Przełom w rozumieniu i opisywaniu pojęcia niepełnosprawności oraz traktowaniu niepełnosprawnych zaczął się dokonywać w latach 50. i 60. XX w. i był związany nie tylko ze zmianami na gruncie obyczajowym, ale przede wszystkim z powstaniem nowej dyscypliny naukowej - socjologii medycyny.

Pierwsze zmiany dotyczyły postrzegania osób niepełnosprawnych psychicznie. Zarówno w Europie, jak i Ameryce pojawiła się fala krytyki wobec zakładów zamkniętych (instytucje opiekuńczo-lecznicze i zakłady psychiatryczne). Socjolog Goffman formułując koncepcję instytucji totalnych, zaliczył do nich właśnie zakłady zamknięte oraz szpitale [11].

Zaczęto zwracać uwagę na ich opresyjny charakter i odchodzić od stosowania przymusu fizycznego. Doprowadziło to do polityki normalizacji polegającej na zwalnianiu z zakładów zamkniętych tych chorych, których nie zdiagnozowano jako niebezpiecznych dla otoczenia (do czego przyczyniał się też rozwój farmakoterapii w zakresie chorób psychicznych). Była to znacząca zmiana w postępowaniu z osobami niepełnosprawnymi. Przez szereg lat niepełnosprawność psychiczna była najbardziej niezrozumianym i najmniej akceptowanym typem niepełnosprawności, a medycyna nie potrafiła znaleźć efektywnej terapii w chorobach psychicznych. Niepełnosprawnych psychicznie zamykano i izolowano (w wiekach wcześniejszych traktując jak opętanych).

Na gruncie prawnym ważnym krokiem w dostrzeżeniu praw niepełnosprawnych psychicznie było uchwalenie przez ONZ w 1971 r. Deklaracji praw osób opóźnionych umysłowo (Declaration on the Rights of Mentally Retarded Persons).

Pojawienie socjologii medycyny wpłynęło więc na zainteresowanie niepełnosprawnością na gruncie naukowym. Stopniowo zaczęło zmierzać w kierunku holizmu, czyli w kierunku opisu funkcjonowania tego zjawiska w szerszym kontekście, czyli w systemie społeczno-politycznym i jej współzależności z systemem. Próby szerszego opisu niepełnosprawności wynikały z rozwoju nauk społecznych i zainteresowania drugim człowiekiem oraz zmierzały do odpowiedzi na pytania: Czym jest niepełnosprawność? Kim są niepełnosprawni?

Badacze opisując sytuację osób niepełnosprawnych, zwracali uwagę na ich codzienne problemy wynikające z pełnionej roli. Taki opis wynikający głownie z empatii czy posiadanej wiedzy okazywał się jednak niepełny. Coraz częściej więc zaczęto udzielać głosu samym zainteresowanym, uznając, że wcześniej byli tego głosu pozbawieni. Wyrazem tego była wydana w 1966 r. zbiorowa praca pt. Stigma - the experience of disability. Ludzie niepełnosprawni zostali w niej przedstawieni jako nieszczęśliwi i wchodzący trudniej bądź niewchodzący w ogóle w reakcje społeczne, jako odsuwani od społeczeństwa i życia społecznego oraz postrzegani jako bezużyteczni. Wszystkie te zjawiska określono jako prowadzące do marginalizacji i wykluczenia społecznego osób niepełnosprawnych, a bycie niepełnosprawnym uznano za wiążące się z naznaczeniem, przypisaniem etykiety oraz piętna nazwanymi stygmatyzacją [12]. 
Podobnie (jako dyskryminowaną mniejszość) opisywał niepełnosprawnych autor Handicaping America, zwracając uwagę na bariery, przed którymi stoją, wynikające z postaw społeczeństwa wobec „innych” [13].

Parsons określił niepełnosprawność jako tzw. dewiację społeczną uniemożliwiającą pełnienie ról w społeczeństwie, rozwijając i rozszerzając tym samym obszar choroby w sformułowanej przez siebie i klasycznej już w socjologii medycyny funkcjonalnej koncepcji choroby [14, 15].

Socjologia medycyny wysunęła postulat demedykalizacji, co znalazło odzwierciedlenie również i w teoriach związanych z socjologią niepełnosprawności. Postulat ten wynikał z negacji postrzegania niepełnosprawności tylko przez pryzmat choroby i opisywania jej wyłącznie pod kątem medycznym. Co prawda rozwój medycyny wpłynął na pojawienie się nowych metod i aspektów związanych z leczeniem oraz rehabilitacją niepełnosprawnych, jednakże medyczny opis niepełnosprawności dotyczył tylko biologicznego aspektu tego zjawiska, pomijając aspekty społeczne. Okazał się więc niepełny i niewyczerpujący.

Opis socjologiczny uzupełnił diagnozowanie medyczne, co wpłynęło na zmiany w definiowaniu niepełnosprawności. Rozszerzony sposób postrzegania niepełnosprawności uwzględniający zarówno aspekty socjologiczne, jak i biologiczne towarzyszył pojawieniu się wielu kierunków badawczych związanych z tym zjawiskiem.

Istotnym nurtem stała się normalizacja akcentująca przywracanie niepełnosprawnych do życia społecznego poprzez udzielenie im kompleksowego wsparcia: psychologicznego, medycznego, technicznego oraz socjalnego.

Znaczna część badaczy (pozytywiści) zaczęła opisywać osobiste doświadczenie niepełnosprawnych, traktując niepełnosprawność jako problem indywidualny i skupiając się na redukcji fizycznego urazu oraz wynikających z niego upośledzenia i cierpienia. Bariera fizyczna została określona jako podstawowy czynnik wpływający na poczucie bycia osobą niepełnosprawną [16].

Zwolennicy postrzegania niepełnosprawności głównie przez pryzmat społeczny krytykowali medykalizację jako zwiększającą uzależnienie osób niepełnosprawnych od lekarzy. Niepełnosprawny uznaje swoją chorobę za stan niepożądany i stara się z niej wyjść. Próba wyjścia musi wiązać się z podporządkowaniem zaleceniom lekarzy i terapeutów oraz wynikającą z tego świadomością własnej zależności [17].

Przeciwstawianie się poczuciu zależności spowodowało więc, że zaczęto kwestionować utożsamienie niepełnosprawności z chorobą (postmoderniści, konstruktywiści i teoria krytyczna). Pojawiła się też krytyka tzw. przemocy symbolicznej określanej jako narzucanie niepełnosprawnym przez pełnosprawnych zarówno dyskursu, jak i sposobu postępowania.

W związku z tym przedstawiciele tzw. nurtu emancypacyjnego zaczęli postulować nie tylko udzielenie głosu osobom niepełnosprawnym, ale także zwiększenie ich roli w życiu publicznym. Problem niepełnosprawności zaczął więc być określany jako polityczny, a polityka stała się narzędziem zmiany zaistniałej sytuacji [18].
Zmiany społeczno-polityczne związane z demedykalizacją znalazły odzwierciedlenie w nowej definicji opracowanej przez Międzynarodową Organizację Osób Niepełnosprawnych (Disabled Peoples' International - DPI). Fizyczne lub psychiczne ograniczenie organizmu określono jako uszkodzenie (impairment), a jako niepełnosprawność zdefiniowano utratę bądź ograniczenie brania udziału w życiu codziennym i społecznym [19].

Takie rozróżnienie pojawiło się już wcześniej w klasyfikacji Światowej Organizacji Zdrowia (World Health Organization WHO) [20]. Niepełnosprawność według tego punktu widzenia jest więc związana przede wszystkim z barierami społecznymi, przed którymi stoi niepełnosprawny.

Dalsze rozróżnienie terminów związanych z niepełnosprawnością pojawiło się w dokumencie WHO z 2000 r., czyli w Międzynarodowej klasyfikacji funkcjonowania, niepełnosprawności i zdrowia (International Classification of Functioning, Disability and Health) [21]. Jako składniki niepełnosprawności określono w niej: uszkodzenie, działanie i uczestnictwo. Wynikają one z tego, że człowiek jest istotą biologiczną, wypełniającą określone zadania w życiu codziennym oraz należącą do określonej grupy społecznej i uczestniczącą w życiu całego społeczeństwa.

W jednej z późniejszych definicji WHO (2007 r.) można zauważyć kolejny krok w definiowaniu niepełnosprawności jako wynikającej z barier społecznych. Są one związane ze stosunkami międzyludzkimi: „niepełnosprawność to wielowymiarowe zjawisko wynikające z wzajemnych oddziaływań między ludźmi a ich fizycznym i społecznym otoczeniem" [22]. Niepełnosprawność wynika więc ze stosunku wobec niepełnosprawnych. Ciężar problemu i jego przyczyna zostały więc przeniesione w obszar postaw ludzi pełnosprawnych [23].

Istotnym zjawiskiem wiążącym się ze zmianą dyskursu naukowego stały się przeobrażenia dotyczące języka dotyczącego niepełnosprawności. W pierwszym rzędzie dotyczyły one języka oficjalnego, później zaczęły one przechodzić do języka codziennego. Używane powszechnie słowo „inwalida” zaczęło być uznawane za przestarzałe i zastąpione słowem „,niepełnosprawny". W języku używanym w ustawodawstwie odchodzi się obecnie i od tego słowa oraz postuluje się używanie terminu „osoba niepełnosprawna” kładąc nacisk na podmiotowość niepełnosprawnego.

Eliminowane są nie tylko słowa mogące kojarzyć się pejoratywnie, ale także te, które mogłyby wskazywać na niepełnosprawnych jako biernych, słabych i potrzebujących pomocy, np. „,bezradność”, ,,bezsilność”, „dysfunkcjonalność”, „, niewydolność”. Postuluje się używanie słów neutralnych, np. „inność”, „perspektywa”, ,wizerunek”, „,kontekst”, które akcentują odmienność osób niepełnosprawnych, nie sugerując jednocześnie ich niższej pozycji. Największa zmiana dokonała się w nazewnictwie dotyczącym niepełnosprawnych umysłowo. Określenia, które jeszcze w połowie XX w. istniały w powszechnym użyciu jako terminy medyczne, np. „debilizm”, „imbecylizm”, „idiotyzm”, dziś są jednoznacznie uważane nie tylko za negatywne, ale i obraźliwe. Z użycia coraz częściej wychodzą także słowa o zabarwieniu mniej pejoratywnym (np.: „upośledzenie”, 
„niedorozwój”, „ociężałość'), ale które mogłyby wskazywać na niższy status osób niepełnosprawnych psychicznie.

Kształtowanie się nowego paradygmatu niepełnosprawności wpłynęło na rozwój polityki społecznej wobec osób niepełnosprawnych w państwach wysokorozwiniętych (głównie w zakresie edukacji i polityki zatrudnienia). Zaczęto tworzyć szkolnictwo specjalne z wykwalifikowanymi kadrami pedagogicznymi mogącymi realizować specjalistyczny program. Wobec systemu edukacji specjalnej wysunięto jednak zarzuty dotyczące oddzielania osób niepełnosprawnych od reszty społeczeństwa i tworzenia dla nich enklaw. Pojawiły się więc trendy integracyjne zmierzające do włączenia edukacji niepełnosprawnych w system edukacji powszechnej, czego wyrazem była deklaracja UNESCO z 1994 r. [24].

Na gruncie polityki zatrudnienia Międzynarodowa Organizacja Pracy (ILO) zalecała w swoim ustawodawstwie integracje pracowników niepełnosprawnych, postulując niedyskryminowanie ich w procesie rekrutacji. Organizacja Narodów Zjednoczonych opublikowała natomiast tzw. wytyczne z Tallina, w których zwracano uwagę na proces kształcenia i szkolenia przyszłych niepełnosprawnych pracowników [25]. Efektem tych zaleceń, a także współdziałania organizacji niepełnosprawnych z insty tucjami prawodawczymi w obszarze polityki zatrudnienia było uchwalenie w Stanach Zjednoczonych w 1990 r. Ustawy o niepełnosprawności (Americans with disabilities). Zakazywała ona dyskryminacji niepełnosprawnych przy zatrudnianiu ich w sektorach komunikacji publicznej, budownictwie, telekomunikacji. Pojawiły się jednak trudności w egzekwowaniu przepisów ustawy. Federalne agencje mające realizować politykę $w$ tym zakresie okazały się niedoinwestowane i nieefektywne, ponadto nie potrafiły pomóc zatrudnionym niepełnosprawnym w znalezieniu miejsca zamieszkania [26].

Akty prawne dotyczące zatrudniania niepełnosprawnych powstawały też w Unii Europejskiej. W 1996 r. Komisja Europejska wydała dyrektywę dotycząca równości szans zatrudnienia [27]. W Traktacie o Unii z 1997 r. znalazła się klauzula o przeciwdziałaniu dyskryminacji niepełnosprawnych w życiu społecznym [28], a w 2000 r. wydano dyrektywę nakazującą państwom członkowskim wprowadzanie ustawodawstwa antydyskryminacyjnego [29].

W ustawodawstwie dotyczącym niepełnosprawnych coraz częściej pojawiały się akty prawne włączające prawa osób niepełnosprawnych do ustawodawstwa ogólnego. Aby jednak rozszerzyć prawa niepełnosprawnych i zwiększyć wagę problemu, zaczęto tworzyć akty szczegółowe związane z tą grupą osób. Znalazło to odzwierciedlenie także w tym, że poszczególne państwa tworzyły w instytucjach i urzędach stanowiska ds. osób niepełnosprawnych.

Efektem ustawodawstwa skierowanego ściśle na ochronę niepełnosprawnych było uchwalenie przez ONZ w 1993 r. porozumienia dotyczącego Standardowych zasad wyrównywania szans osób niepełnosprawnych (The Standard Rules on the Equalization of Opportunities for Persons with Disabilities) [30]. Wśród postulatów tam zawartych, oprócz wyeliminowania dyskryminacji, znalazły się też: nakaz tworzenia przez państwa praw i obowiązków osób niepełnosprawnych wraz z możliwością ich egzekwowania oraz włączanie organizacji i stowarzyszeń skupiających niepełnosprawnych $w$ tworzenie prawa ich dotyczącego.

Najistotniejszymi inicjatywami powstałymi już wcześniej na forum ONZ były: uchwalenie w 1975 r. Deklaracji praw osób niepełnosprawnych [31] (Declaration on the Rights of Disabled Persons), ustanowienie roku 1981 Międzynarodowym Rokiem Osób Niepełnosprawnych (United Nations Year of Disabled Persons), a lata 1983-1992 Dekadą Osób Niepełnosprawnych (United Nations Decade of Disabled Persons).

W 2006 r. również na forum ONZ została uchwalona Konwencja praw osób niepełnosprawnych (Convention on the Rights of Persons with Disabilities) [32]. Zawierała ona m.in. takie postulaty jak poszanowanie autonomii, odmienności i godności osobistej niepełnosprawnych (szczególnie niepełnosprawnych dzieci), a także włączenie ich do aktywnego uczestnictwa w życiu społecznym. W 2012 r. konwencja została ratyfikowana przez Polskę.

Na gruncie Unii Europejskiej realizowano też wiele programów związanych z integracją niepełnosprawnych i włączeniem ich w obszar życia społecznego (Helios I, Helios II, Horizon, Equal, Employment). Obecne priorytety unijne dotyczą przede wszystkim uświadomienia społeczeństwu wagi problemu niepełnosprawności, likwidacji barier architektonicznych oraz wyrównywania szans w dziedzinach takich jak: edukacja, zatrudnienie, opieka zdrowotna, pomoc społeczna.

Największe przeobrażenia w życiu społecznym dotyczyły rozwoju organizacji zrzeszających niepełnosprawnych i były związane ze wzrostem ich aktywności. Organizacje te powstawały z inicjatywy oddolnej, na gruncie trudnych i negatywnych doświadczeń, jak np. izolacja czy obojętność ze strony społeczeństwa, a motywacją ich utworzenia stało się wyjście z impasu polegającego na niskim udziale osób niepełnosprawnych w życiu społecznym. Zaczęły się one opierać na samoorganizacji i samopomocy. Najlepiej rozwijały się w Stanach Zjednoczonych, co było niewątpliwie związane z tradycyjnymi amerykańskimi wartościami: wolnym rynkiem, etosem pracy, suwerennością i wolnością jednostki. Było to podejście nowatorskie w stosunku do wcześniejszego modelu organizacyjnego, kiedy to organizacje niepełnosprawnych były zakładane i kierowanych głównie przez pełnosprawnych oraz były silnie powiązane z instytucjami publicznymi lub same miały taki charakter.

Aktywność niepełnosprawnych w sektorze pozarządowym zmieniała dotychczasowy model polityki społecznej, w którym niepełnosprawni byli tylko jej przedmiotem, będąc jednocześnie uzależnionymi od ludzi zdrowych. Niepełnosprawni zaczęli wpływać na decyzje dotyczące polityki społecznej, stając się jednocześnie jej współtwórcami. Tym samym nastąpiło przejście od statusu pacjenta i konsumenta do statusu współuczestnika systemu oraz od insty tucji publicznych na rzecz pozarządowych grup wsparcia. Organizacje zrzeszające niepełnosprawnych stawały się z czasem coraz liczniejsze i zaczynały przybierać charakter grup nacisku. Zmieniał się także zakres ich działalności, która powoli zaczęła wykraczać poza wąskie 
ramy związane z niepełnosprawnością. Wraz ze zmieniającym się tradycyjnym społeczeństwem stawały się one obok organizacji pacyfistycznych, ekologicznych, antyrasistowskich czy feministycznych częścią tzw. nowych ruchów społecznych charakteryzujących się: radykalizmem, ponadnarodowym charakterem, kontestowaniem tradycyjnego modelu społeczeństwa. Pomimo bycia na marginesie oficjalnego nurtu politycznego, brały one jednocześnie aktywny udział w polityce.

Z czasem żądania organizacji zrzeszających niepełnosprawnych zaczęły dotyczyć prowadzenia aktywniejszej polityki społecznej ze strony państwa. Nierzadko zbiegały się one $\mathrm{z}$ argumentami innych grup nacisku, np. związanych z zawodami medycznymi (takimi jak fizykoterapeuci, rehabilitanci, pracownicy socjalni) czy agencji ubezpieczeniowych. Nastąpiła też zmiana sposobu działania, pojawiły się masowe protesty i demonstracje, a także tzw. akcje bezpośrednie. Polityka prowadzona przez organizacje niepełnosprawnych zaczęła być nazywana tzw. polityką tożsamości. Polegała ona na domaganiu się zwiększenia praw dla niepełnosprawnych i większego poziomu redystrybucji dóbr, a jednocześnie przeciwstawianiu się traktowaniu niepełnosprawnych wyłącznie jako jednostki bierne oraz potrzebujące pomocy. Polityka tożsamości spowodowała więc, że niepełnosprawność zaczęła być postrzegana jako problem społeczny [33, 34].

Ruch niepełnosprawnych zaczął się też jednoczyć na gruncie ponadnarodowym. Przykładem jest utworzenie Międzynarodowej Grupy Niepełnosprawnych (International Disability Caucus) będącej koalicją 70 międzynarodowych, regionalnych i krajowych organizacji. Organizacje zrzeszające niepełnosprawnych oraz związane z nimi inne podmioty trzeciego sektora współpracowały przy opracowaniu i wydaniu dokumentów: Agenda 22 (Sztokholm - 2001 r.) [35] czy Deklaracji Madryckiej (2002 r.) [36] - wydanej przez Europejski Kongres na Rzecz Osób Niepełnosprawnych (European Congress for Disabled People).

Aktywność organizacji zrzeszających niepełnosprawnych wpłynęła na działania prowadzone przez współczesne państwa w ramach polityki społecznej, przy czym poziom i zakres tych działań zależy obecnie od stopnia ich rozwoju. Problemem związanym z istnieniem niepełnosprawności w krajach Trzeciego Świata jest brak zinstytucjonalizowanej pomocy wynikający z niskiego poziomu cywilizacyjnego i złej sytuacji ekonomicznej. Na sytuację niepełnosprawnych wpływa niski poziom opieki medycznej, nieodpowiednia dieta (problem niedożywienia) oraz złe warunki sanitarne i mieszkaniowe związane z ubóstwem. Tylko 1\% niepełnosprawnych ma dostęp do jakiejkolwiek formy rehabilitacji, nie mówiąc już o włączeniu niepełnosprawnych do życia społecznego dzięki podjęciu pracy zawodowej [37].

Wśród osób niepełnosprawnych panuje wysoka śmiertelność (szacuje się, że 95\% dzieci upośledzonych umiera przed 20. r.ż.), na co, oprócz braku odpowiedniej opieki medycznej, mają wpływ: konflikty wojenne (podczas walk w Kambodży wskutek działania min uszkodzeń doznało ok. 100 tys. ludzi), klęski żywiołowe i ekologiczne czy obecna jeszcze w niektórych rejonach tradycja rytualnych okaleczeń [38].
W porównaniu z krajami o wyższym stopniu rozwoju, w państwach słabo rozwiniętych brak znaczących barier architektonicznych, co wynika z ubogiej infrastruktury. Pozytywnym aspektem stosunku do niepełnosprawnych jest ich akceptacja przez społeczeństwo oraz wsparcie im udzielone, choć nie brak też tradycyjnych, stygmatyzujących poglądów, według których niepełnosprawność jest karą za grzechy przodków (Indie, Afryka).

Drugi typ to tzw. kraje rozwijające się. Rozwój przemysłu i urbanizacja powodują tworzenie się wielkich organizmów miejskich. Wpływa to negatywnie na rozwój więzi społecznych i powoduje, że ludzie stają się anonimowi. W dodatku liczne bariery architektoniczne i infrastruktura nieprzystosowana do osób niepełnosprawnych powodują, że ta grupa pozostaje w izolacji. Niepełnosprawni stają się więc „niewidzialni” [39].

Polityka społeczna w zakresie niepełnosprawności w państwach wysokorozwiniętych charakteryzuje się dużą aktywnością w rozwiązywaniu problemów osób niepełnosprawnych, czemu sprzyja wysoki poziom infrastruktury. Jest to o tyle istotne, że w tych państwach występuje wysoki odsetek niepełnosprawnych, co jest związane z niższą śmiertelnością zarówno wśród chorych przewlekle, jak i niepełnosprawnych.

Pomoc osobom niepełnosprawnym w codziennym funkcjonowaniu była podstawowym celem powołania Światowego Programu na Rzecz Niepełnosprawnych (World Programme of Action Concerning Disabled Persons). Liczbę niepełnosprawnych na świecie oszacowano na $500 \mathrm{mln}$, przy czym uznano, że aż $1 / 4$ ludności świata może odczuwać skutki niepełnosprawności (samemu jej doznając lub mając osoby niepełnosprawne w swoim najbliższym otoczeniu). W programie zwraca się uwagę na ubóstwo jako problem szczególnie silnie związany z niepełnosprawnością, a imigrantów i uchodźców jako grupę szczególnie nią zagrożoną [40].

Działania związane z programem obejmują profilaktykę niepełnosprawności (opieka zdrowotna), łagodzenie jej skutków poprzez szeroko pojętą rehabilitację środowiskową (w zakresie medycznym i socjalnym) oraz eliminację wszelkich przejawów dyskryminacji w obszarze zatrudnienia, edukacji, kultury.

Obecnie ukształtował się nowy, tzw. obywatelski model polityki społecznej, który znajduje również zastosowanie w polityce wobec osób niepełnosprawnych. Model ten opiera się na samoopiece, a jego istotnymi elementami są: osoba niepełnosprawna i jej najbliższa rodzina, a także sąsiedzi, znajomi, dalsza rodzina; opieka jest także w znacznej mierze oparta na wolontariuszach. W kręgu osób niepełnosprawnych znajdują się wspominane już grupy samopomocy. Państwo wraz ze swoimi instytucjami pełni tu rolę subsydiarną, a podstawą działania jest szeroka współpraca wszystkich środowisk. Model ten zmierza do upodmiotowienia i aktywizacji niepełnosprawnych, nie zwalniając jednocześnie całkowicie państwa z odpowiedzialności wobec nich.

Aktywizację polityki społecznej, a także wzrost podmiotowości osób niepełnosprawnych, można określić jako procesy pozy tywne. Jednakże obserwuje się także niepokojące zjawiska. Rozwój badań genetycznych oprócz niewątpliwych korzyści stwarza także potencjalne zagrożenia bioetyczne 
związane z życiem osób niepełnosprawnych. Badania prenatalne czy selekcja zarodków mogą prowadzić do prób całkowitej eliminacji osób niepełnosprawnych i pozbawiania ich prawa do życia.

W sporze bioetycznym dotyczącym aborcji jako jedno z kryteriów ją dopuszczających uznaje się niepełnosprawność mającego się urodzić dziecka. Pojawia się tu pojęcie „ciężkiego i nieodwracalnego uszkodzenia płodu” wykrytego podczas badań prenatalnych jako uzasadnienie tzw. aborcji selektywnej (nazywanej także eugeniczną). Jednakże za ciężkie uważa się tylko takie uszkodzenie płodu, które urodzone dziecko skazywałoby na „życie poniżej aksjologicznego minimum”. Jeżeli istniałyby przesłanki wskazujące na to, że osoba niepełnosprawna, mimo swojego stanu mogłaby prowadzić „przynajmniej minimalnie zadowalające życie”, to takie uszkodzenie płodu nie kwalifikowałoby się już jako ciężkie [41]. Trudności w dyskusji o dopuszczalność aborcji selektywnej potęguje fakt, że jest ona niewątpliwie związana z nieostrymi kryteriami. Kto i w jaki sposób miałby definiować czy mające się urodzić dziecko miałoby szanse na „przynajmniej minimalnie zadowalające życie”? Jak jednoznacznie zdefiniować ten termin? Ponadto podejrzenie wystąpienia poważnych wad genetycznych nie zawsze znajduje potwierdzenie po urodzeniu dziecka.

Nawet jeśli mimo tych wątpliwości przyjmie się dopuszczalność aborcji selektywnej, to trudno dopatrzeć się przesłanek do jej wykonania w przypadku zespołu wad wrodzonych trisomia 21 (zespół Downa). W niektórych państwach podejrzenie tej wady genetycznej u dziecka uznaje się za powód przeprowadzenia aborcji nawet w późnym stadium ciąży. Dopuszczenie aborcji w przypadku zespołu Downa oznacza więc zanegowanie prawa do życia osoby niepełnosprawnej. Ta negacja podąża jeszcze dalej, gdyż pojawiają się drastyczne postulaty dotyczące eutanazji niepełnosprawnego dziecka już po jego przyjściu na świat. W marcu 2012 r. głośnym echem odbił się artykuł w czasopiśmie „Journal of Medical Ethics”, w którym autorzy postulują uśmiercanie noworodków z wadą genetyczną, uważając je za „potencjalne osoby”, które nie posiadają moralnego prawa do życia [42]. Jeżeli więc dopuszczalność aborcji w przypadku urodzenia się dziecka niepełnosprawnego oznacza kwestionowanie statusu płodu jako istoty ludzkiej, to postulat zabijania dzieci niepełnosprawnych już urodzonych oznacza całkowite odebranie im człowieczeństwa.

Obecnie toczy się też dyskusja na temat możliwości wprowadzenia dobrowolnej eutanazji osób niepełnosprawnych. W Holandii, która jako pierwsza dopuściła eutanazję w swoim ustawodawstwie, warunkami jej wykonania są „,beznadziejny stan zdrowia chorego" oraz dwukrotnie wyrażona wola śmierci potwierdzona przez co najmniej dwóch lekarzy, jednakże w praktyce już od ponad 20 lat stosuje się obchodzenie tych warunków [43]. Eutanazja jest stosowana w chorobach nowotworowych, ale Niderlandzkie Stowarzyszenie na rzecz Dobrowolnego Zakończenia Życia (Nederlandse Vereiniging voor een Vrijwillig Levenseide - NVVE) postuluje dopuszczenie jej także u osób cierpiących na choroby psychiczne i demencję. Planuje się także zobowiązanie lekarzy do udzielania pacjentom wyczerpujących informacji na temat możliwości dobrowolnej śmierci, do przejmowania inicjatywy i medycznej pomocy zgodnie z wolą samobójców w chwili, gdy ich samounicestwienie się nie powiedzie.

Powyższe fakty wskazują na tendencje zmierzające do uznania życia osób niepełnosprawnych za niepełnowartościowe lub bezwartościowe. Kwestionowanie takiej wartości etycznej, jak szacunku dla życia bądź uzależnianie wartości życia od stanu zdrowia, powoduje potencjalne niebezpieczeństwo podejmowania wobec osób niepełnosprawnych działań zmierzających do ich fizycznej eliminacji, co miało przecież już miejsce w przeszłości (eugenika i eutanazja).

Wyrazem postawy przeciwstawnej mogą być słowa zawarte w przesłaniu papieża Jana Pawła II do uczestników międzynarodowego sympozjum - Godność i prawa osoby z upośledzeniem umysłowym. „Miarą jakości życia w społeczności jest w dużym stopniu opieka, jaką otacza ona najsłabszych i najbardziej potrzebujących, oraz poszanowanie ich ludzkiej godności. Prawa nie mogą być przywilejem tylko zdrowych. Także osobie niepełnosprawnej należy umożliwić uczestniczenie - na miarę jej możliwości - w życiu społeczeństwa i dopomóc w wykorzystaniu całego swojego potencjału fizycznego, psychicznego i duchowego. Tylko wówczas, gdy uznawane są prawa najsłabszych, społeczeństwo może twierdzić, że jest zbudowane na fundamencie prawa i sprawiedliwości" [44].

\section{PIŚMIENNICTWO}

1. Konwencja o prawach osób niepełnosprawnych. Ministerstwo Pracy i Polityki Społecznej. http://www.mpips.gov.pl/spoleczne-prawa-czlowieka/ organizacja-narodow-zjednoczonych/konwencja-o-prawach-osob-niepelnosprawnych/ (1.09.2014).

2. Goffman E.: Piętno: Rozważania o zranionej tożsamości. Tłum. A. Dzierżyński, J. Tokarska-Bakir. Gdańskie Tow. Psychologiczne, Gdańsk 2005.

3. Czupryna A., Poździoch S., Ryś A., Włodarczyk C.: Zdrowie publiczne. Tom 1. Uniw. Wyd. Med. Vesalius, Kraków 2000, 14-15.

4. Topór-Mądry R., Gilis-Januszewska A., Kurkiewicz J., Pająk A.: Szacowanie potrzeb zdrowotnych. Uniw. Wyd. Med. Vesalius, Kraków 2002, 9.

5. Woźniak Z.: Niepełnosprawność i niepełnosprawni w polityce społecznej. Społeczny kontekst medycznego problemu. Wyd. SWPS Academica, Warszawa 2008, 83.

6. Davis F.: Deviance disavowal the management of strained interaction the visibly handicapped. Soc Probl. 1961, 120-132.

7. Kawczyńska-Butrym Z.: Niepełnosprawność- specyfika pomocy społecznej. Wyd. Śląsk, Katowice 1998, 83-85.

8. Barnes C., Mercer G.: Niepełnosprawność. Tłum. P. Morawski. Wyd. Sic!, Warszawa 2008, 43.

9. Sterkowicz S.: Lekarze w służbie bestii. Służ Zdr. 2005, 55-58 (3456-3459).

10. The history of attitudes of disabled people. Wordpress.com. https://attitudes2disability.wordpress.com (1.09.2014).

11. Goffman E.: Asylums: Essays on the social situation of mental patients and other immates. Doublleday Harmondsworth Pelican, New York 1968.

12. Hunt P.: Stigma. The experience of disability. Geoffrey Chapman, London 1966, 145-149.

13. Bowe F.: Handicapping America. Harper and Row, New York 1978.

14. Parsons T:: The social system. Free Press, New York 1951.

15. Parsons T.: The sick role and role of the physician reconsireded. Milibank MeMorial Fund Quarterly. 1975, 53 (3), 257-278.

16. Crow L.: Including all of our lives: Renewing the social model of disability. In: Exploring the divide: Illness and disability. Eds: C. Barnes, G. Mercer. The Disability Press, Leeds 1996, 55-73.

17. Illich I.: Limits of medicine. Medical nemesis: The expropriation of health. Harmondsworth, Penguin 1966. 
18. Safilios-Rotschild C.: The sociology and social psychology of disability and rehabilitation. Parsonski Random House, New York 1970.

19. Proceedings of the First World Congress Disabled Peoples' International. Singapore 30.11-4.12.1981. http://disability-studies.leeds.ac.uk/files/ library/DPI-DPI81.pdf (1.09.2014).

20. International Classification of Impairments, Disabilities and Handicaps. World Health Organisation, Geneva 1980. http://apps.who.int/iris/bitstream/10665/41003/1/9241541261_eng.pdf (1.09.2014).

21. Międzynarodowa Klasyfikacja Funkcjonowania Niepełnosprawności. WHO Geneva, Centrum Systemów Informacyjnych Ochrony Zdrowia. 2009. http://www.csioz.gov.pl/src/files/klasyfikacje/ICF_Polish_version. pdf (1.09.2014)

22. Classification of Functioning, Disability and Health. WHO 2007. http:// search.who.int/search?q=definition + of + disability $+2007 \&$ ie $=u t f 8 \&$ sit $\mathrm{e}=$ default_collection\&client=_en\&proxystylesheet=_en\&output $=\mathrm{xml}$ no_dtd\&oe=utf8 www.who.int/mental_health/evidence/atlas_id_2007. pdf (1.09.2014).

23. Wolfensberger $W:$ Human service policies: The rhetoric versus the reality. Disability and Dependance. Falmer, 1989, 23-42.

24. Salamanca Statement and Framework for Action on Special Needs Education: Word Conference on Special Leeds Education. UNESCO, New York 1994.

25. Tallinn Guidelines for Action on Human Resources Development in the Field of Disability. http://www.un.org/documents/ga/res/44/a44r070. htm (1.09.2014).

26. Promises to Keep: A decade of Federal Enforcement of the Americans with Disabilities Act. National Council on Disability, Washington, DC 2000.

27. Powszechnie obowiązujące rozwiązania prawne dotyczące zakazu jakiejkolwiek dyskryminacji w zatrudnieniu ze względu na wiek i niepełnosprawność. Ministerstwo Pracy i Polityki Społecznej. http://www. mpips.gov.pl/prawo-pracy/prawo-pracy/powszechnie-obowiazujace-rozwiazania-prawne-dotyczace-zakazu-jakiejkolwiek-dyskryminacji-w-zatrudnieniu-ze-wzgledu-na-wiek-i-niepelnosprawnosc/ (1.09.2014).

28. Traktat o Unii Europejskiej. https://polskawue.gov.pl/files/polska_w_ue/ prawo/traktaty/Traktat_z_Maastricht.pdf (1.09.2014).

29. Dyrektywa Rady 2000/78/WE z dnia 27 listopada 2000 r. ustanawiająca ogólne warunki ramowe równego traktowania w zakresie zatrudnienia pracy. www.ptpa.org.pl/public/files/akty_prawne/2000.78.WE.pdf (1.09.2014).
30. Standardowe zasady wyrównywania szans osób niepełnosprawnych. ONZ 1994. Ministerstwo Pracy i Polityki Społecznej. http://www.maps.gov.pl/ download.php?f==userfiles\%2FFile\%@2Fmps\%2FONZ.Doc (1.09.2014).

31. Deklaracja Praw Osób Niepełnosprawnych. Osoby niepełnosprawne na wagę konwencji ONZ. http://www.praca.ffm.pl/onz.html?mo$\mathrm{d}=45 \& \mathrm{p}=2 \& \mathrm{id}=178(1.09 .2014)$.

32. Konwencja Praw Osób Niepełnosprawnych. Rezolucja Zgromadzenia Ogólnego ONZ z 13.12.2006 r. nr A/RES/61/106. http://www.unic.un.org.pl/ dokumenty/Konwencja_Praw_Osob_Niepelnosprawnych.pdf (1.09.2014).

33. Olivier M.: The politics of disablement. Basingstoke, Macmillan 1990.

34. Olivier M.: Understanding disability: from theory to practise. Basingstoke, Macmillan 1996

35. Agenda 22. Władze lokalne. Istruktaż w zakresie planowania polityki na rzecz osób niepełnosprawnych w społecznościavch lokalnych. Tłum. A. Firkowska-Mankiewicz. Zarząd Główny Polskiego Stowarzyszenia na Rzecz Osób z Upośledzeniem Umysłowym, Warszawa 2002. http://www. psouu.org.pl/sites/default/files/publikacje/agenda22.pdf (1.09.2014).

36. Deklaracja Madrycka. niepelnosprawni.pl http://www.niepelnosprawni. $\mathrm{pl} /$ ledge/x/1878 (1.09.2014).

37. Rethinking Care from Disabled People's Perspectives. WHO, Geneva 2001. www.leeds.ac.uk/disability-studies/archiveuk/index (1.09.2014).

38. Overcoming Obstacles to the Integration of Disabled Persons. UN, UNESCO, New York 1995, 9-14.

39. Polityka społeczna a zdrowie. Eds: M. Sokołowska, J. Hołówka. KiW, Warszawa 1978

40. Świat ludziom niepełnosprawnym (zbiór dokumentów i oświadczeń). Ed. A. Hulek. Wyd. PTWzK, Warszawa 1992, 63.

41. Galewicz W: Spór o przerywanie ciąży. Bioetyka. Wprowadzenie. Interdyscyplinarne Centrum Etyki UJ. http://www.incet.uj.edu.pl/dzialy. php?l=pl\&p=32\&i=3\&m=22\&z=0\&n=2\&k=9 (2.02.2015).

42. Giubilini A., Minerwa F.: After-birth abortion. Why should the baby live? J Med Ethics. http://jme.bmj.com/content/early/2012/03/01/medethics-2011-100411.fulltext (1.09.2014).

43. Żylicz Z:: Eutanazja w Holandii. Medicus. 1992, 1, 3, 21-22.

44. Jan Paweł II: Ludzie najsłabsi i najbardziej potrzebujący w życiu społeczeństwa. Przesłanie: Godność i prawa osoby z upośledzeniem umysłowym. Opoka. http://www.opoka.org.pl/biblioteka/W/jan_pawel_ii/ przemowienia/uposledzenie_05012004.html (1.09.2014). 